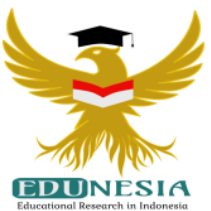

\title{
Pengaruh Metode Pembelajaran Montessori Berbantuan Media Movable Alphabet Dalam Meningkatkan Keterampilan Membaca Permulaan Siswa Kelas I SDN 57 Di Kecamatan Marusu Kabupaten Maros
}

\author{
Ernawati \\ Magister Pendidikan Dasar, Universitas Muhammadiyah Makassar, Indonesia \\ Corresponding Email: ernawatirandanan@gmail.com, Phone Number :0823 xxxx xxxx
}

\author{
Article History: \\ Received: Nov 16, 2020 \\ Revised: Nov 19, 2020 \\ Accepted: Nov 20, 2020 \\ Published: Jan 01, 2021
}

Keywords:

Alphabet, Beginning

Reading, Montessori,

Movable.

Kata Kunci:

Alphabet, Membaca

Permulaan,

Montessori, Movable.

\section{How to cite:}

Ernawati, E. (2021). Pengaruh Metode Pembelajaran Montessori Berbantuan Media Movable Alphabet Dalam Meningkatkan Keterampilan Membaca Permulaan Siswa Kelas I SDN 57 Di Kecamatan Marusu Kabupaten Maros. Edunesia: Jurnal Ilmiah Pendidikan, 2 (1): 153-161.

This is an open access article under the CC-BY-NC-ND license (c) (i) $\odot$
Abstract: The purpose of this study was to learn the ability to read the first grade SDN 57 Bulu-bulu in marusu district maros regency Using the montessori method to help alphabet media and to learn of the significant effects of using the montessori method to help the alphabet to improve literacy skills of the first class I SDN 57 Bulu-bulu Marusu district maros. The type of research used is quasi-research With a design of the design non test control group. The method used was experimental. Research shows that students study results are being observed Of the mean posttest class experiments of $80.60 \%$, whereas of the mean posttest control class of $72.20 \%$. Control class gain index by 0.51 . Test $t$ shows value $t$ (3.394) > tables (2.001) and sig value (2-tailed) 0.05 is 0.001 which means the Montessori method Partially covered in alphabet media Significantly the results of learning to read First class I SDN 57 Bulu-bulu in marusu district maros regency 2020/2021.

Abstrak: Tujuan dalam penelitian ini adalah untuk mengetahui kemampuan membaca permulaan siswa kelas I SDN 57 Bulu-bulu di Kecamatan Marusu Kabupaten Maros dengan metode Montessori berbantuan media Movable Alphabet dan untuk mengetahui adanya pengaruh signifikan penggunaan metode Montessori berbantuan media Movable Alphabet dalam meningkatkan keterampilan membaca permulaan siswa kelas I SDN 57 Bulu-bulu Kecamatan Marusu Kabupaten Maros. Jenis penelitian yang digunakan adalah QuasiExperimental Research dengan desain Non Equivalent Kontrol Group Design. Metode yang digunakan adalah metode eksperimen. Hasil penelitian menunjukkan bahwa hasil belajar siswa di lihat dari nilai mean posttest kelas eksperimen sebesar $80,60 \%$, sedangkan mean posttest kelas control sebesar $72,20 \%$. Indeks gain $<\mathrm{g}>$ kelas eksperimen sebesar 0,63 sedangkan $<\mathrm{g}>$ kelas control sebesar 0,51. Hasil uji $t$ menunjukkan nilai $t_{\text {hitung }}(3,394)>$ tabel $(2,001)$ dan nilai Sig. (2-tailed) $<0,05$ yaitu 0,001 yang artinya metode Montessori berbantuan media Movable Alphabet secara parsial berpengaruh signifikan terhadap hasil belajar membaca permulaan siswa kelas I SDN 57 Bulu-Bulu di Kecamatan Marusu Kabupaten Maros tahun ajaran 2020/2021. 


\section{A. Pendahuluan}

Kemajuan ilmu pengetahuan dan teknologi yang berkembang sangat cepat dapat diperoleh dari berbagai media elektronik seperti: Televisi, radio, internet dan lain sebagainya, selain itu dapat juga diperoleh dari media cetak seperti: koran, majalah, jurnal dan lain-lain, dengan menggunakan cara membaca misalnya. Dengan demikian agar aktivitas membaca mampu menuruti perkembangan ilmu dan teknologi tersebut, sepenuhnya dibutuhkan, mengapa? Karena membacalah orang dengan mudah mendapatkan petunjuk dan penjelasan, menambah ilmu pengetahuan baru, serta keahlian yang baru. Seluruh yang didapatkan lewat membaca tersebut memberi peluang terhadap seseorang dapat mempertinggi daya nalarnya, mempertajam pandangannya, dan memperluas wawasannya (Winarto dkk, 2016). Oleh sebab itu, aktivitas membaca adalah aktivitas yang betul-betul dibutuhkan bagi mereka yang mau berkembang dan mempertinggi kemampuan dirinya.

Menurut hasil penelitian membuktikan bahwa tingkat penguasaan membaca siswa di Indonesia tergolong masih sangat rendah jika disandingkan dengan negara-negara lain (Wahyuni, 2018). Programmer for International Student Assessment (PISA), merupakan pengkajian internasional terhadap hasil literasi membaca, matematika dan sains.

Menurut hasil perolehan studi PISA, membuktikan bahwa rata-rata skor prestasi literasi membaca, matematika dan sains siswa Indonesia berada di bawah rata-rata skor internasiional. Hasil survei PISA dalam tiga survei yang pernah diikuti Indonesia menunjukkan hasil yang sangat memprihatinkan. Pada survei tahun 2000 Indonesia peringkat 39 dari 41 negara yang disurvei. Pada tahun 2003, Indonesia menduduki posisi 39 dari 40 negara partisipan. Sementara itu, untuk survei tahun 2006, Indonesia menduduki posisi 48 dari 56 negara partisipan dengan skor rata-rata membaca yang diperoleh siswa Indonesia hanya 393 (Solihat, 2020).

Selanjutnya, hasil studi Progress in International Reading Literacy Study (PIRLS) tahun 2006 dalam bidang membaca pada anak-anak kelas IV sekolah dasar di seluruh dunia di bawah koordinasi The International Association for the Evaluation of Educational Achievement (IEA) yang dikuti 45 negara/negara bagian, baik berasal dari negara maju maupun dari negara berkembang, hasilnya memperlihatkan bahwa peserta didik Indonesia berada pada peringkat ke 41 (Dores \& Setiawan, 2018).

Keterampilan membaca adalah keterampilan dasar pada jenjang Pendidikan dasar dan sekolah dasar (SD) merupakan satuan atau Lembaga pendidikan yang menurunkan keterampilan dasar tersebut seperti halnya yang dikemukakan dalam Bab II pasal 6 ayat 6 PP No. 19 tahun 2005 tentang Standar Nasional Pendidikan (Nasution, 2017). Disamping itu, lembaga SD selaku wadah pendidikan formal diharapkan agar mampu mengatasi kerumitan yang dialami anak untuk menumbuhkan kemampuan berbahasa termasuk kemampauan membaca.

Pelaksanaan pembelajaran di sekolah kelihatannya belum mampu memecahkan kesulitan-kesulitan belajar yang dialami oleh siswa. Untuk permasalahan seperti ini kadang kala belum mendapatkan kepedulian dari para guru. Sebagaimana hal tersebut diperjelas kembali oleh Chatib (2012) yang mengemukakan bahwa beberapa tenaga pendidik atau guru yang setiap harinya bergerak di dalam proses pendidikan, cenderung belum mampu mengenal benar siswa yang mengalami kerumitan dalam belajar. Suprihatin (2015) mengemukakan bahwa siswa akan berkembang secara optimal melalui perhatian guru yang positif, begitu pun sebaliknya. 
Berdasarkan hasil observasi langsung di SDN 57 Bulu-Bulu Kecamatan Marusu Kabupaten Maros pada kelas I tanggal 3-5 Oktober 2019 terlihat beberapa siswa yang mengalami kesulitan dalam membaca permulaan, hal ini dibenarkan oleh masing-masing wali kelas 1 di SDN 57 Bulu-Bulu tersebut. Salah satu bentuk kesulitan membaca permulaan tersebut yaitu kesulitan mengenali huruf. Ada siswa yang belum mengenal beberapa huruf dengan baik atau bahkan sebagian besar bentuk huruf. Ada pula yang mengalami kesulitan dalam membedakan huruf yang bentuknya mirip seperti huruf " $b$ " dengan " $d$ ", huruf " $p$ " dengan " $q$ ", huruf " $m$ " dengan " $w$ " dan sebagainya. Mereka juga sulit membedakan huruf yang bunyinya hamper sama yaitu antara huruf " $\mathrm{f}$ " dengan " $\mathrm{v}$ ". Kesulitan selanjutnya adalah siswa belum memahami lambang bunyi vocal dan konsonan. Wardani (2014) menyebutkan bahwa Ketika hal demikian berlangsung, sehingga anak-anak belum mampu melaksanakan decooding, yakni membaca tulisan sesuai dengan bunyinya.

Media Pembelajaran berbasis metode Montessori ini telah dikembangkan oleh Wulandari (2018) melalui penelitian Riset dan Pengembangan. Dan sudah pernah diuji cobakan kepada siswa untuk melihat pengaruh media terhadap keberhasilan membaca permulaan siswa. Namun, media tersebut belum pernah diujicobakan di kabupaten Maros khususnya pada sekolah dasar di SDN 57 Bulu-bulu Kecamatan Marusu Kabupaten Maros. Maka dari itu penelitiakan melihat bagaimana pengaruh metode pembelajaran Montessori berbantuan media pembelajaran Movable Alphabet materi membaca permulaan siswa kelas I SDN 57 Bulu-bulu Kecamatan Marusu Kabupaten Maros. Atas dasar tersebut, ini sangat penting untuk diteliti sebab membaca permulaan merupakan kemampuan yang paling pokok untuk setiap siswa untuk dapat mengikuti proses pembelajaran di sekolah dasar.

Berdasarkan uraian tentang permasalahan di atas maka rumusan masalah dalam penelitian ini adalah, 1) Bagaimana kemampuan membaca permulaan siswa kelas ISDN 57 Bulu-bulu Kecamatan Marusu Kabupaten Maros dengan metode Montessori berbantuan media Movable Alphabet? 2) Apakah ada pengaruh signifikan penggunaan metode Montessori berbantuan media Movable Alphabet dalam meningkatkan keterampilan membaca permulaan siswa kelas I SDN 57 Bulu-bulu Kecamatan Marusu Kabupaten Maros?.

\section{B. Metode}

Metode yang digunakan dalam penelitian ini adalah metode penelitian kuantitatif. Desain yang digunakan adalah Non Equivalent Control Group Design. Populasi dalam penelitian ini adalah seluruh siswa kelas I A dan kelas I B SDN bulu-Bulu di Kecamatan Marusu Kabupaten Marosse banyak 60 siswa. Sedangkan sampel dalam penelitian ini adalah seluruh siswa kelas I yang ada pada populasi, sehingga teknik yang digunakan dalam pengambilan sampel menggunakan Non Probability Sampling dengan teknik sampel jenuh/sampel total. Adapun lokasi yang menjadi fokus penelitian adalah SDN 57 Bulu-Bulu di Kecamatan Marusu Kabupaten Maros.

Adapun prosedur dalam penelitian ini yaitu:1) Melaksanakan observasi, wawancara dan mengambil data nilai mata pelajaran Bahasa Indonesia siswa kelas I SDN 57 Bulu-Bulu di Kecamatan Marusu Kabupaten Maros. 2) Berdasarkan hasil observasi yang ada di lapangan, wawancara, dan data nilai, maka Langkah selanjutnya adalah menentukan sampel penelitian pada kelas eksperimen dan kelas kontrol dengan menggunakan teknik Sampel Total. 3) Menyusun kisi-kisi tes uji coba. 4) Menyusun instrumen tes uji coba berdasarkan kisi-kisi yang ada. 5) Menguji cobakan instrumen sebagai instrumen tes hasil belajar pada kelas eksperimen dan kelas kontrol. 6) Melaksanakan pretest terhadap kelas 
kontrol dan kelas eksperimen. 7) Melaksanakan pembelajaran dengan menggunakan metode Montessori berbantuan media Movable Alphabet pada kelas eksperimen. 8) Melaksanakan posttest pada kelas eksperimen dan kelas control. 9) Menganalisis hasil penelitian. 10) Menyusun hasil penelitian.

Teknik pengumpulan data yang digunakan yaitu: 1) observasi, 2) tes, dan 3) dokumentasi. Instrumen pengumpulan data menggunakan instrumen berupa soal pilihan ganda dan instrumen observasi. Teknik analisis data yang dipakai yakni analisis data deskriptif dan inferensial.

\section{Hasil Dan Pembahasan}

a. Data Hasil Belajar Pretest

Data hasil belajar pretest pada kelas kontrol dan kelas eksperimen menunjukkan adanya tingkat kesamaan. Semua siswa di kedua kelas tersebut tidak ada yang mencapai standar KKM sekolah pada mata pelajaran Bahasa Indonesia yaitu 70. Adapun data hasil belajar pretestsiswa di kelas kontrol dan kelas eksperimen dapat dilihat pada tabel 1.

Tabel 1.

Data hasil belajar pretest pada kelas kontrol dan kelas eksperimen

\begin{tabular}{|c|c|c|c|}
\hline \multirow{3}{*}{ No } & \multirow{3}{*}{ Interval } & \multicolumn{2}{|c|}{ Pretest } \\
\hline & & Kelas Kontrol & Kelas Eksperimen \\
\hline & & $F$ & $\mathbf{F}$ \\
\hline 1 & $83-100$ & - & - \\
\hline 2 & $76-82$ & - & - \\
\hline 3 & $70-75$ & - & - \\
\hline 4 & $51-69$ & 11 & 13 \\
\hline 5 & $0-50$ & 19 & 17 \\
\hline & Jumlah & 30 & 30 \\
\hline & Tuntas $(\geq 70)$ & - & - \\
\hline & Tidak Tuntas $(<70)$ & 30 & 30 \\
\hline & Tertinggi & 60 & 60 \\
\hline & Terendah & 20 & 33 \\
\hline & Rata-rata & $42,6 \%$ & $47,5 \%$ \\
\hline
\end{tabular}

Pada Tabel 1 terlihat bahwa hasil belajar pretest siswa kelas kontrol dan kelas eksperimen pada mata belajaran Bahasa Indonesia materi membaca permulaan memiliki hasil belajar yang tidak tuntas. Pada kelas kontrol nilai tertinggi adalah 60 dan nilai terendahya itu 20. Sedangkan untuk kelas eksperimen skor tertinggi adalah 60 dan nilai terendah adalah 33. Sementara itu, rata-rata nilai di kedua kelas tersebut masih kurang atau minim. Di bawah ini adalah diagram distribusi frekuensi Pretest: 


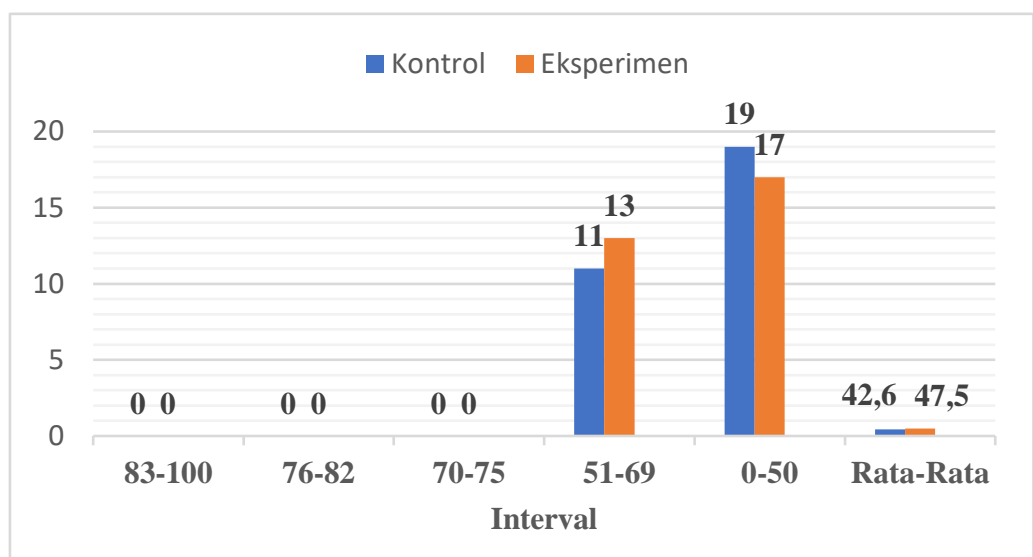

Gambar 1. Data hasil belajar pretest pada kelas kontrol dan kelas eksperimen

b. Data Hasil Belajar Posttest

Data hasil belajar posttest di kedua kelas yaitu kelas kontrol dan kelas eksperimen memperlihatkan adanya perbedaan yang sangat signifikan. Pemberian perlakuan sebanyak $2 x$ pertemuan mendapatkan hasil belajar yang meningkat di kedua kelas tersebut. Hal tersebut dapat dilihat pada hasil belajar siswa setelah diberikan perlakuan mencapai ketuntasan klasikal > 50\%. Lihat tabel 2.

Tabel 2.

Data hasil belajar posttest kelas kontrol dan kelas eksperimen

\begin{tabular}{|llcc|}
\hline \multirow{2}{*}{ No } & \multirow{2}{*}{ Interval } & \multicolumn{2}{c}{ Posttest } \\
\cline { 3 - 4 } & & Kelas Kontrol & Kelas Eksperimen \\
\cline { 2 - 4 } & & $\mathbf{F}$ & $\mathbf{F}$ \\
\hline 1 & $83-100$ & 3 & 12 \\
\hline 2 & $76-82$ & 7 & 8 \\
\hline 3 & $70-75$ & 12 & 6 \\
\hline 4 & $51-69$ & - & 4 \\
\hline 5 & $0-50$ & $\mathbf{3 0}$ & $\mathbf{3 0}$ \\
\hline & Jumlah & $\mathbf{1 8}$ & $\mathbf{2 6}$ \\
\hline & Tuntas ( $\geq \mathbf{7 0 )}$ & $\mathbf{1 2}$ & $\mathbf{4}$ \\
\hline & Tidak Tuntas (<70) & $\mathbf{9 3}$ & $\mathbf{9 3}$ \\
\hline & Tertinggi & $\mathbf{6 0}$ & $\mathbf{6 0}$ \\
\hline & Terendah & $\mathbf{7 2 , 2} \%$ & $\mathbf{8 0 , 6} \%$ \\
\hline
\end{tabular}

Berdasarkan Tabel 2 tersebut di atas mampu diamati bahwa ketuntasan siswa ratarata di kelas control adalah sebesar $72,2 \%$ dari 30 siswa. Sedangkan pada kelas eksperimen ketuntasan belajar siswa meningkat dimana sebelum diberi perlakuan rata-rata hasil belajar kelompok eksperimen sebesar 47,5\%. Namun setelah diberi perlakuan hasil rata-rata belajar siswa kelas eksperimen meningkat menjadi 80,6\%. Di bawah inia dalah diagram distribusi frekuensi Pretest: 


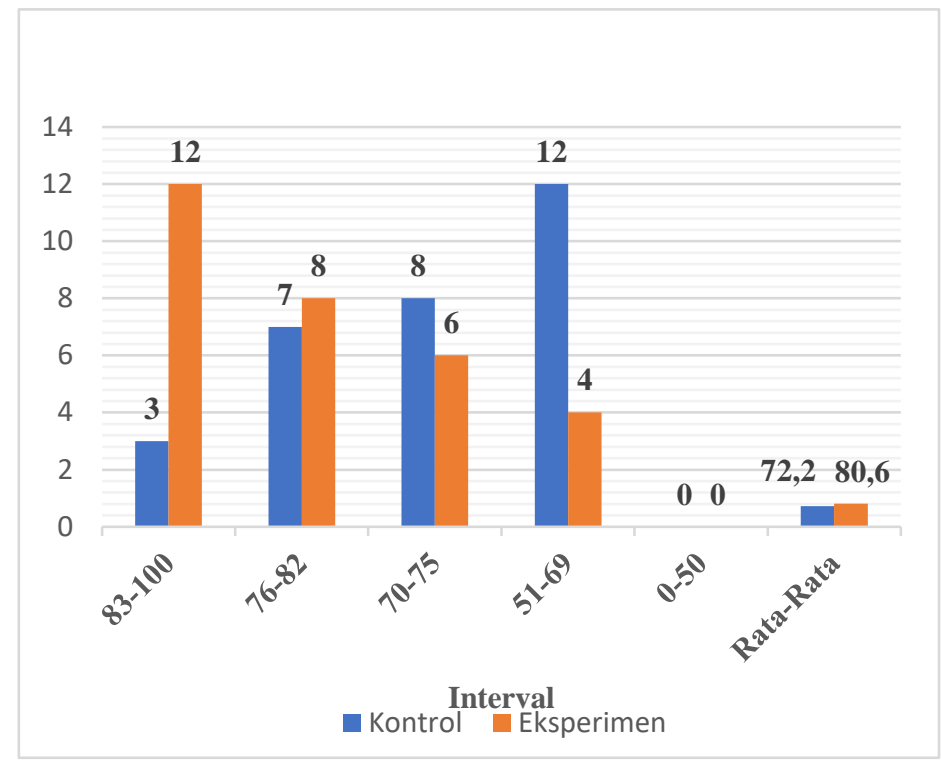

Gambar 2. Data hasil belajar posttest kelas kontrol dan kelas eksperimen

c. Perbedaan Nilai Rata-Rata Posttest Kelas Kontrol dengan Nilai Posttest Kelas Eksperimen Setelah kedua kelas diberiperlakuan, dimana kelas control diajar menggunakan metode pembelajaran Montessori dan kelas eksperimen diajar menggunakan metode pembelajaran Montessori berbantuan media Movable Alphabet maka dapat diperoleh perbedaan hasil belajar di kedua kelas tersebut. Selengkapnya lihat pada tabel 3.

Tabel 3.

perolehan skor rerata kelas kontrol dan kelas eksperimen

Descriptive Statistics

\begin{tabular}{lllllll}
\hline & & & & & & $\begin{array}{l}\text { Std. } \\
\text { Deviation }\end{array}$ \\
\cline { 2 - 7 } & Statistic & Statistic & Statistic & Statistic & $\begin{array}{l}\text { Etror } \\
\text { Error }\end{array}$ & Statistic \\
\hline Posttest Kontrol & 30 & 60 & 93 & 72,20 & 1,688 & 9,245 \\
\hline $\begin{array}{l}\text { Posttest } \\
\text { Eksperimen }\end{array}$ & 30 & 60 & 93 & 80,60 & 1,810 & 9,912 \\
\hline Valid N (listwise) & 30 & & & & & \\
\hline
\end{tabular}

Pada Tabel di atas terlihat bahwa perolehan skor rerata di kedua kelas memiliki selisih sebesar 8,4\% dengan deskripsi 72,20 pada kelas kontrol dan 80,60 untuk kelas eksperimen. Hasil tersebut membuktikan bahwa terdapatnya perbedaan antara kelas kontrol dan kelas eksperimen. Adanya perubahan secara signifikan setelah diberikan perlakuan pada masing-masing kelas lebih terlihat pada kelompok eksperimen.

\section{d. Uji Gain}

Uji gain dimaksudkan untuk menguji seberapa besar peningkatan hasil belajar siswa. Uji gain adalah selisih antara skor perolehan pretest dan posttest. Data yang dipakai 
adalah data yang diambil dari nilai posttest dikurang inilai pretest pada kedua kelas yang diteliti. Nilai tersebut dilakukan perhitungan untuk dapat memperoleh indeks gain (g).

Tabel 4. Uji Gain

\begin{tabular}{llllll}
\hline No Jenis Kelas & \multicolumn{3}{c}{ Nilai Mean } & <g $>$ & Kategori Gain \\
\hline \multicolumn{5}{c}{ Pretest } & Posttest \\
\hline 1 & Kontrol & 42,60 & 72,20 & 0,51 & Sedang \\
\hline 2 & Eksperimen & 47,50 & 80,60 & 0,63 & Sedang \\
\hline
\end{tabular}

Berdasarkan tabel 4 di atas indek gain di kelompok kontrol memperlihatkan angka sebesar 0,51. Angka tersebut termasuk dalam kategori sedang. Pada indek gain eksperimen di peroleh angka sebesar 0,70. Kategori gain untuk kelompok eksperimen adalah tinggi. Meskipun hasil gain mendapatkan kategori sama-sama sedang antara kelas kontrol dan kelas eksperimen tetapi kelompok kontrol memiliki nilai diatas kelas kontrol Hal ini membuktikan bahwa peningkatan yang terjadi pada kelas eksperimen lebih baik dari pada kelas kontrol.

\section{e. Uji Dua Pihak (Uji T)}

Uji T dilakukan setelah memperoleh data output gain score. Pengujian ini digunakan untuk mengetahui ada tidaknya pengaruh signifikan metode Montessori berbantuan media Movable Alphabet terhadap keberhasilan membaca permulaan siswa kelas I SDN 57 BuluBulu di Kecamatan Marusu Kabupaten Maros. Hasil pengujian uji T tersebut dapat dilihat pada tabel berikut:

Tabel 5. Uji T

\begin{tabular}{|c|c|c|c|c|c|c|c|c|c|}
\hline \multicolumn{10}{|c|}{ Independent Samples Test } \\
\hline & & \multicolumn{8}{|c|}{$\begin{array}{l}\text { Levene's } \\
\text { Test for } \\
\text { Equality of } \\
\text { Variances t-test for Equality of Means }\end{array}$} \\
\hline & & & & & & $\begin{array}{l}\text { Sig. } \\
(2- \\
\text { taile }\end{array}$ & $\begin{array}{l}\text { Mean } \\
\text { Differ }\end{array}$ & $\begin{array}{l}\text { Std. } \\
\text { Error } \\
\text { Differ }\end{array}$ & $\begin{array}{c}95 \% \\
\text { Confidence } \\
\text { Interval of the } \\
\text { Difference } \\
\end{array}$ \\
\hline & & $\mathrm{F}$ & Sig. & $\mathrm{t}$ & $\mathrm{df}$ & d) & ence & ence & Lower Upper \\
\hline \multirow[t]{2}{*}{$\begin{array}{l}\text { Hasil } \\
\text { Belajr } \\
\text { Siswa }\end{array}$} & $\begin{array}{l}\text { Equal } \\
\text { variancs } \\
\text { assumd }\end{array}$ & 118 & ,732 & 3,394 & 58 & 001 & 8,400 & 2,475 & $3,446 \quad 13,354$ \\
\hline & $\begin{array}{l}\text { Equal } \\
\text { variance } \\
\text { not } \\
\text { assumed }\end{array}$ & & & 3,394 & $\begin{array}{l}57,7 \\
21\end{array}$ & ,001 & 8,400 & 2,475 & $3,446 \quad 13,354$ \\
\hline
\end{tabular}

Berdasarkan tabel 5 di atas dapat diambil kesimpulan bahwa kedua kelas adalah homogen atau memiliki varian yang sama. Kehomogenan dapat dilihat pada kolom $t$-test 
for equality of means yang memperlihatkan nilai Sig (2-tailed) lebih kecil dari nilai signifikansi 0,05 yaitu 0,001 .

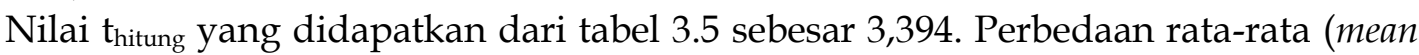
difference) sebesar 2,475 dan perbedaan berkisar antara -13,354 sampai 3,446 (lihat pada lower dan upper). Untukt table sendiri di dapatkan hasil sebesar 2.001. Dengan ini, dapat disimpulkan bahwat hitung (3.394) $>$ tabel $(2,001)$. Artinya, Ho ditolak dan Ha diterima yaitu metode Montessori berbantuan media Movable Alphabet berpengaruh secara signifikan terhadap hasil belajar membaca permulaan siswa kelas I SDN 57 Bulu-Bulu di Kecamatan Marusu Kabupaten Maros. Hal ini berarti bahwa ada pengaruh yang signifikan antara hasil belajar membaca permulaan siswa kelas eksperimen dan kelas kontrol.

Berdasarkan hasil penelitian dan pengolahan data, didapatkan hasil belajar siswa berbeda antara kelas kontrol dan kelas eksperimen. Perbedaan tersebut dapat dilihat pada table perhitungan uji gain terhadap hasil belajar pretest dan posttest kelas kontrol dan eksperimen. Uji gain dipakai untuk melihat bagaimana peningkatan hasil belajar baik dikelas control maupun di kelas eksperimen. Untuk analisis uji gain, didapatkan hasil indek gain $<\mathrm{g}>$ kelas control sebesar 0,51 , sedangkan untuk kelas eksperimen uji indeks gain $<\mathrm{g}>$ sebesar 0,63. Hal tersebut membuktikan bahwa kelas eksperimen lebih baik dari kelas kontrol.

\section{Kesimpulan}

Berdasarkan hasil analisis data penelitian, maka diperoleh simpulan yaitu 1) Kemampuan awal membaca permulaan siswa kelas I di SDN 57 Bulu-Bulu masih sangat rendah ini dibuktikan dengan nilai pretest dimana kelas I A hanya mendapatkan nilai ratarata sebesar $42,60 \%$, sedangkan pada kelas I B hanya mendapatkan rata-rata sebesar $47,50 \%$. Namun setalah diberi perlakuan pada masing-masing kelas dimana kontrol menggunakan metode pembelajaran Montessori dan pada kelas eksperimen diterapkan metode pembelajaran Montessori berbantuan media Movable Alphabet terlihat kemampuan membaca siswa meningkat dikedua kelas tersebut meskipun hasil belajar pada kelas eksperimen jauh lebih meningkat daripada kelas kontrol, dimana sebelumnya kelas I A hanya mendapatkan $42,60 \%$ meningkat menjadi $72,20 \%$ dan pada kelas eksperimen nilai rata-rata yang hanya 47,50\% kemudian meningkat menjadi 80,60\% . 2) Metode Pembelajaran Montessori berbantuan media Movable Alphabet berpengaruh secara signifikan terhadap hasil belajar membaca permulaan siswa kelas I SDN 57 Bulu-bulu. Analisis uji hipotesis yang dilakukan dengan uji gain dan uji $\mathrm{T}$ telah membuktikan bahwa terdapat pengaruh yang signifikan antara hasil belajar membaca permulaan pada siswa kelas eksperimen dibandingan dengan siswa kelas kontrol. Hasil belajar siswa di kelas eksperimen yang mencapai ketuntasan belajar di atas KKM lebih banyak dibandingkan pada kelas kontrol. Pada kelas eksperimen ketuntasan siswa ketuntasan siswa mencapai 80,20\% siswa (26 dari 30 siswa). Sedangkan ketuntasan di kelas control sebesar 72,20\% siswa (18 dari 30 siswa).

\section{Ucapan Terima Kasih}

Ucapan terima kasih disampaikan kepada seluruh pihak yang telah berperan dan berkontribusi dalam penelitian ini, sehingga penelitian dapat terlaksana dengan baik. 


\section{Daftar Pustaka}

Chatib, M. (2012). Sekolah anak-anak juara: berbasis kecerdasan jamak dan pendidikan berkeadilan. Kaifa.

Dores, O. J., \& Setiawan, B. (2018). Pengembangan LKS Berbasis Dongeng untuk Meningkatkan Literasi Matematis Siswa Sekolah Dasar Se-Kota Sintang. Jurnal Pendidikan Matematika Indonesia, 3(2), 62-65.

Nasution, A. (2017). Analisis kurikulum Pendidikan Agama Islam dalam Kurikulum Tingkat Satuan Pendidikan di Sekolah Dasar Negeri 200514 Labuhan-Labo Kecamatan Padangsidimpuan Tenggara Kota Padangsidimpuan (Doctoral dissertation, IAIN Padangsidimpuan).

Solihat, A., Hendracipta, N., \& Yuliana, R. (2020). Pengembangan Media Puppet Book Berbasis Pembelajaran Multiliterasi Pada Siswa Sekolah Dasar. Jurnal Bidang Pendidikan Dasar, 4(2), 134-144.

Suprihatin, S. (2015). Upaya guru dalam meningkatkan motivasi belajar siswa. Jurnal Pendidikan Ekonomi UM Metro, 3(1), 73-82.

Wahyuni, H. I. (2018). Kebijakan Media Baru Di Indonesia:(Harapan Dinamika Dan Capaian Kebijakan Media Baru Di Indonesia). Ugm Press.

Winarto, Y. T., Suhardiyanto, T., \& Choesin, E. M. (Eds.). (2016). Karya Tulis Ilmiah Sosial: Menyiapkan, Menulis, dan Mencermatinya. Yayasan Pustaka Obor Indonesia.

Wulandari, S. (2018). Metode Montessori "Media The Stamp Game" Untuk Meningkatkan Kemampuan Berhitung (Penjumlahan) Pada Siswa Sekolah Dasar Yang Slow Learner (Doctoral dissertation, University of Muhammadiyah Malang). 